\title{
Religious Syncretism and Context of Buddhism in Medieval Nepal
}

\section{Introduction}

\section{Khadga Man Shrestha*}

Nepal is land of the great sages. Buddhism and Hinduism are practiced in Nepal hand in hand. Peaceful co-existence is the sticking feature of the country. The cultural heritage of the country is very rich. Mutual respect, co-existence cooperation and peace are the cultural features of the country. The country never experienced religious conflict rather people lived in harmony helping each other. People are inspired by the high ideals of the great thinkers. They venerate them and worship them in different holy shrines. People have ideals to go to immortality from mortality. They wish salvation while alive and even after death. Spirituality has remained the common goal of the people. Philanthropic ideas inspire them. As such, they believe in mysticism. They think of different ways and means or ground, path and fruit for realization of salvation. Their sentiment takes them to the realm of the God.

The fundamental basis of Buddhism is four Brahmavihars i.e. Maitri, Karuna, Mudita and Upekshya. Maitri (friendship) is the first basis of Buddhism. Buddhists equate Maitreya with Maitri (friendship).Cultivation of friendship even with the foe has been the prime concern of Buddhism, which is expected to become as deep as sea, which is synonym to Sunyata. Sunyata itself is the seed of truth. Maitri is symbolic in meaning. Without knowing, the meaning of Maitri Buddhism cannot be understood. Maitreya Bodhisattva is also equated with Mahasattva. The latter is regarded as the primordial Buddha in Nepal. Thus, Maitreya Buddha appears as the future Buddha. In some Viharas, Maitreya Bodhisattva is enshrined as the Kwapadyo. The Kwapadyo of Nandisar Vihara previously was Maitreya Bodhisattva. Musumbahal and Jamabahal and some Viharas in Patan also have Maitreya as the main deity. Lord Buddha, according to the Buddhist myth handed over the throne of Tushita heaven to Maitreya Buddha before he became Buddha. ${ }^{1}$ Regarding the antiquity of worshipping Maitreya Buddha, the image of Maitreya Bodhisattva was developed

Mr. Khadga Man Shrestha is the former Director of Department of Archeology, Nepal and a freelance researcher.

1. Yajna Man Vajracharya, Maitri, Maitreya Bodhisattva, Kathmandu: Mani Singh Mahavihar, N.S 1125, pp. 1-3; Patriarch Chih I and Master T'ien Ju, Pure Land Buddhism, New York: Sutra Translation Committee of U.S.A. and Canada, 1992, pp. 23 -26. 
during the time of Kanishka (78-101 A.D.). It is also stated that Maitreya Buddha came into lime light since the third century B.C. Lichchhavi inscriptions refer Mahasanghika Bhikshu Sangha. ${ }^{4}$ Maitreya Buddha is also referred in the evocation of Lokanath. Bodhisattva images were found in Lumbini and Hadigaon excavations. ${ }^{5}$ These references make clear that in the beginning of the Christian era Mahayana Buddhism was popular and it was practiced in Nepal. The tradition of worshipping Buddha and Bodhisattvas images and also images of other Buddhist deities made Buddhism of Nepal syncretic in nature.

\section{Development of Religious Syncretism in Nepal}

In order to know the syncretic nature of Buddhism, one has to visualize general history of development of Buddhism. Buddhists in Nepal believe that all the three schools of Buddhism originated during the time of Lord Buddha. During the various phases of development of Buddhism, the Buddha was regarded as a teacher, Mahapurusha (a great man) and Chakravartin (universal ruler) in the first phase. Popular veneration of the Buddha developed into the Buddha cult. He was presented as the exalted one. Buddha Dharma was developed in doctrinal statement and scholastic interpretations were made. In the second phase, Buddhism spread rapidly and monastic became the focal point. In the third phase, esoteric forms of Mahayana tradition developed and Vajrayana texts were created. The Bodhisattva concept and Buddha culminated in the Buddhist pantheons and elaborated rituals in Mahayana tradition developed. Similarly, Buddhist institutions started to declined in the fourth phase. In the fifth phase, Buddhism was reinterpreted by nontraditional scholarship. There are five paths - the path of discipline and virtuous conduct (Silamarga), b) the path of meditative concentration (Dhyanamarga), the path of transcendent comprehension (Prajnamarga), the path of devotional practice (Bhaktimarga), (the path of complete reliance upon the efficacy of compassion (Buddhanusmritimarga). ${ }^{9}$

However, the development of Buddhism in Nepal indicates that Buddhism made compromise with Shaivism, Vaishnavism and Shaktism and Nath sects. Consequently, it appeared syncretic. Tantrism and Bhaktimarga synchronized Buddhism with other sects in an amicable manner. The Buddha was deified and worshipped. In some instances

4. Dhanavajra Vajracharya, Lichchhavikalin Abhilekh, Kirtipur: Research Center for Nepal and Asian Studies, 2053, pp. 508-510.

5. National Museum, Buddhist Collection of National Museum of Nepal, Kathmandu: Department of Archaeology, 1998, p. 69.

9. Richard A. Gard, Great Religions of Modern Man, New York: Washington Square Press, 1963 pp. 15-25; Khadga Man Shrestha, 'Baudha Dharmama Bhakti Marga’, Pashupati Kshetra, Year 9, Vol. 11, November 2002, pp. 38-42. 
Khadga M. Shrestha: Religious Syncretism ...

image of Lord Shiva was placed along with five transcendental Buddhas in the dome of Stupa. It is attested by the artifacts found in the Tukan Bahal Chaitya belonged to the Lichchhavi period.

Mahayana is comprised in terms of worship, devotion and salvation. S. Radhakrishnan writes that Buddhism explains philosophical issues in a scientific way. It does not accept the existence of soul. It was based on non-soul concept. ${ }^{10}$ In the question of King Milinda, Acharya Nagasena explained that that there is nothing like soul in Buddhism. ${ }^{12}$ The concept of many Buddhas and Bodhisattvas, as well as messengers of God and Saints is included in Mahayana Buddhism. The philosophy of Buddhism was, in fact, on the line with existing Indian thought and the philosophy. The Upanishads had even ridiculed priest craft and ritualism and minimized the importance of caste. Buddhism and Hinduism acted and re-acted each other in spite of their dialectical conflicts. ${ }^{15}$ Ambedkar also opines that the theory of Jatakas appears analogous to the Brahmanic theory of incarnation. ${ }^{16}$ He has adopted linear approach in his perception. He opines that the Buddha was influenced by the tenets of Sankhya Philosophy. According to which truth must be supported. For attesting truth, there are the ways of perception and inference. His next tenet is related to casualty- creation and its cause. Kapil has denied the existence of someone who has created the universe. Ambedkar writes that the Buddha based his logics and facts on three things of Kapila. He accepted that reality must rest on proof, thinking must base on rationalism. No logical or factual basis exists for the presumption that God exists. He accepted that there was suffering in the universe. ${ }^{17}$ According to Vedic tradition, the form of soul is Sachitananda i.e. truth, feeling and delight. According to Veda, soul is eternal and nondestructive. Vedic tradition believes that God is the architect and protector of the universe. Buddha said that the world is full of suffering. Every thing is temporary. Mahayana believes on metaphorical approach. Syncretism is the characteristic feature of Mahayana Buddhism.

\section{Accounts of Chronicles}

Nepalese chronicles also mention about syncretism in Nepal. Himavatskanda mentions that Buddha came from Mahachina (great

10. S. Radhakrishnan, Bharitiya Darshan, Delhi: Rajpal and Sons, 1998, p. 321.

12. Dunda Bahadur Vajracharya, Milinda Prasna, Lalitpur: Bir Purna Pustak Sangrahalaya, pp. 34-38

15. Jawaharlal Nehru, The Discovery of India, New Delhi: Indian Council for Cultural Relations, 1981, p. 114.

16. B.R Ambedkar, The Buddha and His Dhamma, Nagpur: Buddha Bhoomi Publication, 1997, p. 21.

17. Ibid., p. 86. 
China) and existed in the form of Dharmadhatu and Paramananda. This version has Hindu flavor. Citing Nepal Mahatmya, it mentions that a God, in the form of Buddha came from Saurastra and made penance of Vajrayogini. ${ }^{19}$ This account of Vamsavali best represents syncretism in Nepal from Hindu point of view. According to the description, the Buddha came to Jnana Tirtha with his disciples and led the demons to the path of peace. Bhasa Vamsavali also mentions that during the time of Yakshya Gupta, son of Vishnu Gupta, Sakyasimha as an incarnation of Vishnu imparted knowledge on Buddhism among the demons and made them Buddhists. ${ }^{20}$ Although the accounts are imaginary, it tried to explain religious tolerance in the society. Moreover, the sequence of events does not tally the period of the Guptas and the Buddha. Again, these legends indicate the compromising tendency of Shaivites in Nepal. Thus, the religious syncretism in Nepal became a common phenomenon. The literary sources such as chronicles, Mahatmyas (glorifications), Avadanas, Puranas and Sutras etc. glorify deities. The cosmology and cosmogony of Buddhism refer the glorification and deification of cosmic elements. They are symbolically venerated in the form of five transcendental Buddhas. The Hindus equate various Buddhist deities with Panchayana deities. The Panchayana devatas include Surya, Ganesh, Shakti, Sadashiva and Vishnu. In it Ganesh represents Apa (water), Maheshvari or Shakti -Tej or Agni (fire or light) Lord Shiva-Prithivi (earth) and Lord Vishnu represents Akash (Sky). This is the similar case among the Buddhist deities or the Buddhas. These cosmic elements are mentioned in the name of different deities in Kapil Tantra ${ }^{21}$ Ratnavali describes Panchavinirmite Dehe Pancha Tattvam ca Punargate" (Human body is made of five cosmic elements and finally it has its extinction on these elements). ${ }^{22}$ Gayatri Mantra of Hindus includes the Mantra (spell) like Om Bhu Bhurva Svaha (Homage to earth or God of Universe). In the same way, the Buddhists pay homage to Avalokitesvara with the spell of Om Mani Padme Hum (Jewel on the lotus). ${ }^{23}$ Buddhist holy text highly praises Padmapani Lokesvara for water. Amitabha is worshipped as Surya (sun God). Indra is also equated with Akshobhya and Brahma with Padmapani Lokesvara. Both the Hindus and Buddhist philosophy highly

19. 'Nepal Deshko Itihas', Ancient Nepal 12, Kathmandu: Department of Archeology, 1970, p. 26.

20. Ibid., p. 23; Nayanath Paudel (ed.) Bhasha Vamsavali, Kathmandu: Department of Archeology, Nepal National Library, 2020 V.S., p. 45.

21. Hari Ram Joshi, Abhinava Sanskriti Kosh, Lalitpur: Joshi Research Institute, 2058 V.S, p. 183.

22. Ibid., p. 166.

23. Hari Ram Joshi, ‘Om Mani Padme Hum', Ancient Nepal 24, Kathmandu: Department of Archeology, 1973, p. 29. 
praise the importance of cosmic elements as eternal elements. Both of them include syllable $\mathrm{Om}$ in the Mantra. Om symbolizes Brahma, Vishnu, Maheshvara, and Shakti. The Hindu saints interpret Sunyata of Buddhism in the theistic manner and it denotes infinitive status.

Bhakti cult has united the Hindus and Buddhists. Lokesvara cult is the uncommon model of syncretism in Nepal. Padmapani Lokesvara is venerated as the creator. Svayambhu Purana glorifies the Adi Buddha. Svayambhu is self sprouted. Narrating a story of creation the Buddhist mythology mentions that Vipasvi, one of the seven Buddhas, wished a seed of lotus to sow in the Nagadaha. He sowed it in Nagdaha. Svayambhu appeared on the lotus, which had thousand petals. Thus Svayambhu, the supreme Buddha, God of three realms originated in itself. $^{27}$ The Adi Buddha meditated and created the five transcendental Buddhas. The root of Svayambhu is referred as Guhyesvari or Nairatmadevi. Nepal Mahamya glorifies Lord Shiva. As Guhjesvari is mentioned as the Shakti of Shiva, Svayambhu is equated with Shambhu or Lord Shiva. It is an uncommon model of syncretism. Svayambhu was also venerated in ancient times during the chariot festival of Matsyendra Nath. On the top of the chariot of Karunamaya, Svayambhu is embellished. Sylvain Levi writes - when Bandhudatta Acharya and Narendradeva brought Matsyendra Nath from Kamarupa Kamakhya and arrived at Kooduwal mountain located to the north of the valley, a great procession followed them. At the time of entering the valley, Bandhudatta politely dismissed the Gods of outside with gifts and summoned the Gods of Nepal. He organized a great procession. Four Bhairavas undertook to carry the God willingly captive in phial. Brahma swept the street singing Vedas; Vishnu blew the conch, Mahadeva slatted about water, Indra held the parasol, Yama burnt incense, Baruna spread rain water, Kuvera riches; Agni splendour, Vayu carried the banner, Nairitya brushed obstacles aside, Isanas dispersed demons. Bandhudatta and Narendradeva alone saw this spectacle; the laymen only saw birds and beasts. ${ }^{28}$ In the same way, Lalitvistara includes the account that all the deities of heaven hailed the Buddha Sakyamuni at his birth in Lumbini garden. In a Mahayana Buddhist Vihara of Lumbini the visitors gaze at the picture of celebrating the Buddha's birthday by the different Hindu Gods. It is the best expression of religious syncretism in Nepal.

Dipankar Buddha is also mentioned as the first Buddha among the twenty-eight Buddha's. ${ }^{29}$ He was the Buddha of Satyayuga. King

27. Shakya, f. n. no. 24, p. 3.

28. Sylvain Levi, 'Nepal', Ancient Nepal 53-56, Kathmandu: 1979-1980, p. 19.

29. A. Fuhrer, Antiquities of Buddha Sakyamuni's Birthplace in the Nepalese Terai, Kathmandu: The Nepal Studies Past and Present, 1996, p. 19. 
Sarvananda was a great devotee of Dipankar Buddha. .The people of his country who came in search of the king made the image of Dipankar Buddha. ${ }^{30}$ Mahavatthu Avadana includes a very popular legend of Dipankar Buddha who is venerated by the Buddhists and the Hindus. Spiritual devotion has great value and labor is dignified as the morals of the legend of Dipankar Buddha. The Buddhist Vamsavali also includes a legend. It shows the faith of the Buddhists in metempsychosis.

Wright's chronicle mentions myths and legends relating to the visit of Shankaracharya and religious discussions between the Hindus and Buddhists in ancient times. During the Lichchhavi rule in Nepal Buddhism was in equal footing with other religions. Although the Lichchhavi kings followed Vaishnavism and Shaivism, the Bhikshu Sangh worked as custodian of morality of the people. Some of the Lichchhavi rulers became Bhikshus during their old age and made vihars. Buddhism flourished during the Lichchhavi period. Although Anuparam denounced the Buddhists as atheists, illogical, the Avalokitesvara cult was very popular during that time. During the ancient period Shaiva communities and the Buddhist Sanghas enjoyed considerable autonomy. $^{31}$

\section{Syncretism During the Early Medieval Period}

Buddhism appears to have reached its zenith during the transitional period in the early medieval time. Some of the kings of early medieval period abdicated to enter Buddhist monkhood. ${ }^{32}$ She mentions that during that period Patan at least, with its interlocking web of Viharas, had become essentially a Buddhist university centre. ${ }^{33}$ In the early medieval period, there is reference of the visit of Shankaracharya Dandi Swami of Kashi Agnimath. The inscription now exhibited at the National Museum Chhauni attests it. The text of the inscription is published in Kantipur Abhilekh Suchi. ${ }^{34}$ As the inscription is in mutilated form, term tuh shasti is interpreted by adding, cha, assuming it to become Chatushasti. Thus, historians speculated the inscription dates to

30. Daniel Wright, History of Nepal, New Delhi: Asian Educational Services, 1990, pp. 87-88 and 131.

31. Mary Slusser, Nepal Mandala: A Cultural Study of Kathmandu Valley, Vol. I, New Jersey: Princeton University Press, p. 275.

32. Ibid., p. 281.

33. Ibid., p. 281

34. Kantipur Abhilekh Suchi mentions the remark-XXIV - on a slab of stone, which now lies in Nepal Museum. In the inscription, the name of King Anandadeva is mentioned. His reign lasted in between N.S. 267 and 28. 
Khadga M. Shrestha: Religious Syncretism ...

N.S.264. ${ }^{35}$. However, it is true that Shankaracharya of Kashi Agnimath visited Nepal and made the princes and the king of Nepal as the followers of Shaivism, which is testified by the epigraphic evidence mentioned above. The installation of Shree Yantra and the worship of Kirtimukh Bhairava and offering of animal sacrifice indicated the compromise between the Shaivites and the Buddhist tantra practitioners.

\section{Syncretism in Later Medieval Period}

In the later medieval period, Jayasthiti Malla reorganized the Nepalese society. Jayasthi Malla's militant Brahmanical policy and fanaticism or the prejudices disturbed the popular cult of Buddhism. He made Brahmanical purge of Buddhism and infringed the sentiment of the Buddhists. ${ }^{37}$ With the help of five orthodox Brahmans of Mithila, Kanyakubja and South India, he made a code named Nepalrastra Shastra. ${ }^{38}$ In the same way, L Petech opines that Jayasthiti Malla codified the whole structure of the Nepalese society in a strictly orthodox Hindu frame. He was a devotee of Vishnu as witnessed by the title of Daitya Narayana, which is mentioned in the preface to the Avinava Raghavananda Natak. Goddess Manesvari was his protecting deity. But he was also a devotee of Shiva. ${ }^{39}$ The above-mentioned observations seem to be baseless in view of Svayambhu inscription of Raj Harsha Bhallok dated N.S. 492. It mentions that Jayasthiti Malla is depicted as the one who administered the country with the merit of Buddha \{Palite tatra kalen Buddhopunnodayenach\}. King Jayarajdeva is mentioned with the title of Indra and Jayasthiti Malla as Upendra. The inscription mentions Rajnoridropendra samano. ${ }^{40}$ The Gopalrajavamsavali mentions him as the incarnation of the Buddha compared with eight guardian deities. ${ }^{41}$ Petech writes that Jayasthiti Malla put the Buddhist monks on footing parity with Brahmanic priests. For the Buddhist laity no distinction was necessary. ${ }^{42}$ In N.S. 507 , he went to Bungamati and stayed there for fourteen days with his sons for the chariot festival of

35. Jnanmani Nepal, Pahupatinathko Darshan Sparshan Poojan Sambandhama Samikshya, Kathmandu: Mahesh Raj Pant, 2043 V.S., p. 50.

37. Rajendra Ram, History of Buddhism in Nepal, Patna: Jana Bharati Prakashan, 1977, p. 196

38. Ibid., p. 199.

39. Luciano Petech, Medieval History of Nepal, Rome: ISMEO. Pp. 139-140.

40. Hari Ram Joshi, 'Madhyakalin Abhilekh', Ancient Nepal 53-56, Kathmandu: 1980, pp. 40-41.

41. Dhanavajra Vajracharya and Kamal Prakash Malla (eds.), The Gopalrajvamsavali, Kathmandu: Nepal Research Centre, 1985, p. 20.

42. Petech, f. n. no. 39, p. 184. 
Matsyendranath. In his eulogy, we find Svayambhukrita Baraprasadita. ${ }^{43}$ Jayasthiti Malla took the title of Svayambhu Prasad Sevaka. ${ }^{44}$ He was tolerant to all the religions within his domain.

Shiva Simha Malla (1585-1614 A.D.) consecrated Svayambhu Chaitya after renovation. He offered an umbrella in N.S. 715. An inscription and a Thyasaphu mention about the renovation of Svayambhu Chaitya during the reign of Shiva Simha Malla. He also preserved the Tukan Bahal Chaitya of Hyumat Tole in N.S. 734. In the same way, King Pratap Malla is also credited for erecting Pratappur and Anantapura shrines at Svayambhu. He erected Vajrayana deities there. He also offered Vajra and Vajradhatu Mandala to Svayambhu and established a Guthi by donating 150 Kavindra Malli coins for illumination at Svayambhu in N.S. 783. He donated land for pature in the east of Svayambhu. His court was adorned by the great scholars like Lamba Karna Bhatta, Kumaril Bhatta and Jamana Gurubhaju of Mani Singh Mahavihar of Musum Bahal, Kathmandu. The later was his Vajracharya Guru. King Pratap Malla was tolerant to all religions. ${ }^{45}$ He entered Shantipur tantric shrine at Svayambhu for the welfare of his subjects. To remove draught in the country, he is said to expose the Mahamegha Sutra in the sun. It was written with the blood of the snakes which is revealed from an inscription dated N.S.778. He had taken the title of Srestha Devata Charana Sevaka. An inscription of Bishnumati dated N.S. 783 attests his devotion to Svayambhu. He also composed hymns to praise Svayambhu. In the same way Jaya Prakash Malla, the last Malla ruler of Kantipur was also devoted to Buddhism. In the year 1757 A. D. he renovated Svayambhu Stupa. He issued a special decree for the protection of forest at Svayambhu. He also composed a hymn praising the Svayambhu Chaitya. ${ }^{46}$

With regard to the rulers of Patan, almost all the rulers showed respect to Matsyendranath. They minted coins in the name of Lokanath or Matsyendranath. ${ }^{47}$ Although Siddhinarsingh Malla was a devout follower of Lord Vishnu, he was devoted to Buddhism as well. He made regulations on management of Viharas summoning the chiefs of the Viharas of Patan. He is said to have installed an image of Lokesvara at

43. Jagadish C. Regmi, 'Gopal Vamsavali’, Ancient Nepal 22, Kathmandu: 1973, p. 13.

44. Shakya, f. n. no. 24, p. 145.

45 Perceval Landon, History of Nepal, Vol. I, Delhi: Adarsha Enterprises, 2001, p. 4-7.

46 . Shakya, f. n. no. 24, pp. 233-235.

47. Hem Raj Shakya, Shri Karunamaya Bungamavalokiteshvara Sanskritik Pristhabhumi, Lalitpur: Raj Kumar Shakya, N.S.1111, p. 16. 
Khadga M. Shrestha: Religious Syncretism ...

the uppermost floor of Krishna temple at Patan. He also declared himself the 'devotee of Lokesvara'. He incises Bungama Lokiteshvara on the ivory window with golden tympanum of Sundari Chowk at Patan Darbar. $^{48}$ His son Shree Nivas Malla too promoted the cult of Matsyendranath. He made 'codification of rites and ritual of Matsendranath. Public participation was made obligatory in the chariot festival of Matsyendranath. ${ }^{49}$ During his reign, the Buddhist celebration of Samekmahadana was celebrated with great enthusiasm. Jodhaju Shakya of Mahabauddha temple in Patan offered a golden throne to the king. During the Samyak festival, the ruling King is worshipped as a Bodhisattva

During the medieval period, there was no difference between Buddha and Shiva for the laity. Both gods were equally venerable for all. The inscription of Rudramatidevi, a daughter of King Shree Nivas Malla dated N.S. 801 in the temple of Amarapur at Matsyendra Bahal at Bungamati village mentions - Svasti Dwijaya Svayambhu Svabhu Sambhu rupam sada Yoginam cha Matsyendranatham. (Let all be happy, to it the Brahmans express in the form of Svayambhu, Svabhu, and Shambhu, It is Matsyendranath among the Yogis). Matsyendranath is venerated by the Buddhists as Avalokitesvara, the Vaishnavites worship the deity as Vishnu, the Shaivites worship the deity as Shiva, the Yogis as Matsyendranath, the Shaktas as Shakti, the Saurya sect as the sun. It is a common deity for all the prevailing sectssects. Yog Narendra Malla, the son of Shree Nivas Malla had embellished Shristikanta Llokeshvara in the golden window of Keshav Narayan Chowk at Patan Durbar according to the account of Gunakarandavyuha Sutra. ${ }^{50}$

Bhaktapur is regarded as the stronghold of Hinduism. In the Lichchhavi period, Buddhism developed in Bhaktapur. An inscription found at Chyamha Simha area mentions about the Mahasanghika Bihikshuni Sangha. To the south of Dattatreya, there was a row of Viharas. It is said that Shankaracharya established Dattatreya destroying a Vihara. Nevertheless, the establishment of Snehamandap at the Durbar Square in Bhaktapur during the time of Jitamitra Malla proves the popularity of Jogichakra. Bhupatindra Malla also constructed the five storied temple, which was designed by a Vajracharya Guru from Chaturbrahma Vihara. The temple is also adorned with Buddhist deities. We have more than twenty-two Viharas in Bhaktapur still extant. Those Viharas were built during the medieval period, which symbolizes

48. Ibid., pp. 13 and 17.

49 . Dhanavajra Vajracharya, Madhyakalka Abhilekh, Kirtipur: RCNAS, 2056 V.S., pp. 170-181.

$50 \quad$ Shakya, f. n. no. 47, p. 17. 
religious tolerance of the Malla rulers. Ranajit Malla, the last ruler of Bhaktapur composed a hymn wishing good harvest with the blessing of Svayambhunath. In the hymn, it is mentioned Vairochana as the primordial Buddha. Similarly, other Buddhas are also praised in the hymn. The hymn attests the fact that King Ranajit Malla prayed for the blessings of the five transcendental Buddhas. ${ }^{51}$

Thus, Nepal had a glorious tradition of religious tolerance. One sect respected the other. Spiritualism brought about unity among the followers of all religions. For the laity, there was no difference between Buddha and Shiva. The Hindus worship Buddhist Chaityas and the Buddhists visit Hindu temples for worship. A Chaitya of Nhyakan Bahi at Lagan Tole has both Buddhist and Hindu deities. The Chaitya has the images of Shakyamuni Buddha in Bhavishya Vyakarna Mudra in the east, Lord Shiva holding Trisul, Damaru, Varmala and Kamandalu in the south, Brahma in meditative posture with peacock as the vehicle in the west and Lord Vishnu holding Sankha, Chakra, Gada, Padma as attributes in the north. Thus there exist Hindu deities in the place of Akshobya, Ratnasambhava, Amitabha and Amoghasiddhi. In some Chaityas the Shiva phallus supplants Vairochana Buddha while enshrining at the Garbhagriha. In one of the Chaityas of Kasthamandapa located to the east of Ashok Vinayak in Kathmandu, a Shivalinga is enshrined at the centre of the dome. The Lagan Chaitya resembles to the Shakti Linga The Shakti Linga includes Brahma, Vishnu, Maheshvara and Mahashakti as the four faces of Mukhalinga on four directions on the lethal phallus placed on Jalahari. Thus, two main sects of Nepal are so related that the temples and Stupas stand side by side. There is no religious struggle in Nepal. Religious syncretism of Nepal is the best model Nepal mainly practices Mahayana Buddhism. Mahayana borrowed the concept of Supreme God, the conception of Bodhisattva and the conception of heaven from the Vedic religion.

51. Shyaka, f. n. no. 24, p. 239. 